\title{
69th ISE Annual Meeting 参加報告
}

\section{平賀健太郎（東京農工大学大学院 工学府 生命工学専攻）}

2018 年 9 月 2 日から 7 日までイタリア共和国北部の都市, ボローニャで開催された 69th Annual Meeting of the International Society of Electrochemistryへの参加に際し, 平 成 30 年度前期（第 46 回）「若手研究者の国際交流支援」 の助成を賜りました。心より御礼申し上げます。ボロー ニャはサン・ペトロニオ大聖堂やボローニャの斜塔をは じめとした歴史的建造物が数多く保存されており, かの 有名なルイージ・ガルヴァーニの生まれ育った街として も知られています。

学会では大きく 21 の Symposiumが設けられ，私はその 中でも Symposium 3 "Bioelectrochemistry Returns to the Home of Galvani”に主に出席しました。このSymposium では初日にガルヴァーニの生い立ちや彼の研究について の紹介から始まり, 酵素, 抗体, 核酸などを分子認識素 子として用いるバイオセンサーやバイオ燃料電池, 微生 物燃料電池, タンパク質の酸化還元反応の解析など主に 生体分子を用いた電気化学反応に関する多数の報告があ りました。中でも酵素を用いた埋め込久型のバイオ燃料 電池についての報告について興味をひかれ, 改めて埋め 込み型のバイオセンサー・バイオ燃料電池の開発が難し いものであることを認識しました。

私自身は同 Symposium の中で, “Rational Enzyme Engineering for Development of 2.5th Generation Biosensor" というタイトルで口頭発表を行いました．私の所属する 研究グループではこれまでに amine reactive phenazine ethosulfate (arPES) という, 簡便に酵素を修飾できる電子 メディエーターを用いて酵素-電極間の擬直接電子移動 (quasi-DET) を可能としたバイオセンサーを提唱してきま した。ところが，乳酸センサー素子として汎用されてい る乳酸酸化酵素 (Lactate oxidase; LOx) は arPES で修飾して も quasi-DETが観察されないという課題に直面していまし

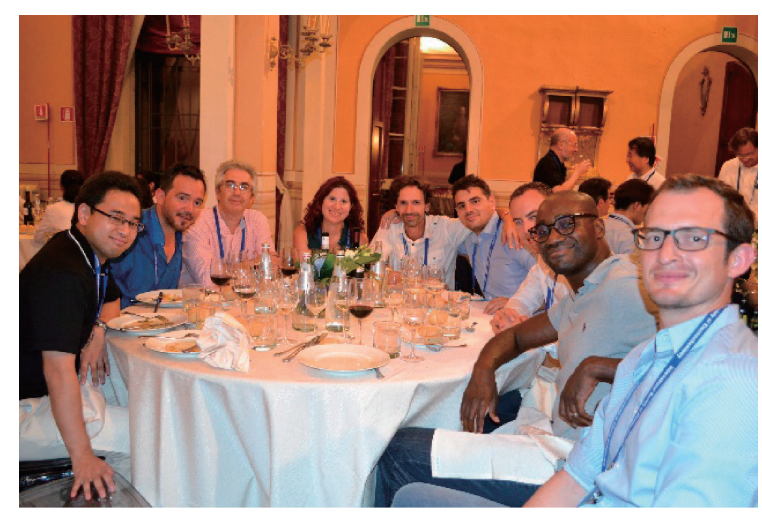

写真. Banquetにて（一番左，著者）

た。本研究では, この課題を解決するために LOxに対し て変異導入を行い, quasi-DETが観察される位置に arPES が修飾できるように変異導入箇所を設計することで, こ の問題を解決し, 高感度な乳酸濃度測定を実現できたこ とを報告しました。講演後には同じ分野を研究している グループとの活発な議論を行うことができました。

また，9月 5 日はすべての Symposiumが午前中しかなく， 午後はフリータイムとして設けられていたので市街地に 赴きました。最古の大学とされ, ガルヴァーニが学生時 代に通った旧ボローニャ大学を見学したり, ボローニャ の斜塔に登ったりしました。旧ボローニャ大学の前には ガルヴァーニ像があり, 数百年前にカエルの脚の筋肉が 電流によって痤攣する現象がまさにこの地で発見された のだと思い, そこから現在までの電気化学の発展の歴史 に思いを馳せずにはいられませんでした。

最後になりましたが, 今回の国際会議参加に際し, ご 支援いただきました電気化学会及び, 関係者の方々にこ の場をお借りして御礼申し上げます。 